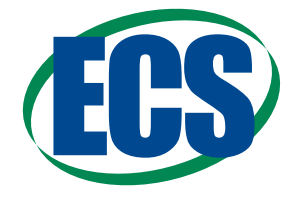

\title{
An Analysis Protocol for Three-Electrode Li-Ion Battery Impedance Spectra: Part II. Analysis of a Graphite Anode Cycled vs. LNMO
}

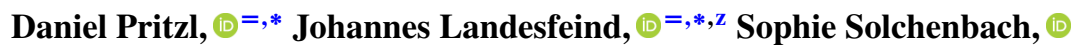 \\ and Hubert A. Gasteiger**
}

Chair of Technical Electrochemistry, Department of Chemistry and Catalysis Research Center, Technical University of Munich, Munich, Germany

\begin{abstract}
Lithium-Ion batteries consisting of $\mathrm{LNMO}\left(\mathrm{LiNi}_{0.5} \mathrm{Mn}_{1.5} \mathrm{O}_{4}\right)$ cathodes and graphite anodes show severe capacity fading at elevated temperatures due to a damage of the solid electrolyte interface (SEI) on the anode. Hence, a detailed investigation of the anode with electrochemical impedance spectroscopy (EIS) can provide valuable insight into the phenomenon of anode degradation. In this study, we use a modified version of our novel impedance procedure (Part I of this study), where the anode impedance is measured at non-blocking conditions (10\% SOC) and blocking conditions $(0 \%$ SOC) in a graphite/LNMO full-cell with a gold wire micro-reference electrode (GWRE). We show that during cycling an ionic contact resistance $\left(R_{\text {Cont.Ion }}\right)$ at the separator/anode interface evolves, which is most likely caused by manganese dissolution from the high-voltage cathode (LNMO). By simultaneously fitting EIS spectra in blocking and non-blocking conditions, we can deconvolute the anode impedance evolving over 86 cycles at $40^{\circ} \mathrm{C}$ into contributions of: a) the separator resistance $\left.\left(R_{\mathrm{Sep} .}\right), \mathrm{b}\right)$ the true charge transfer resistance $\left(R_{\mathrm{CT}}\right)$, and, $\left.\mathrm{c}\right)$ the ionic contact resistance $\left(R_{\text {Cont.Ion }}\right)$ evolving at the separator/anode electrode interface. We also show that the main contributor to a rising anode impedance is the ionic contact resistance $\left(R_{\text {Cont.Ion }}\right)$.

(C) The Author(s) 2018. Published by ECS. This is an open access article distributed under the terms of the Creative Commons Attribution Non-Commercial No Derivatives 4.0 License (CC BY-NC-ND, http://creativecommons.org/licenses/by-nc-nd/4.0/), which permits non-commercial reuse, distribution, and reproduction in any medium, provided the original work is not changed in any way and is properly cited. For permission for commercial reuse, please email: oa @ electrochem.org. [DOI: 10.1149/2.0461810jes]
\end{abstract}

(cc) BY-NC-ND

Manuscript submitted April 25, 2018; revised manuscript received June 25, 2018. Published July 11, 2018. This was Paper 402 presented at the Seattle, Washington Meeting of the Society, May 13-17, 2018.

In view of the growing concerns with regards to cobalt supply constraints for Lithium-Ion batteries, ${ }^{1} \mathrm{LiNi}_{0.5} \mathrm{Mn}_{1.5} \mathrm{O}_{4}$ (LNMO) as cathode active material with a theoretical energy density of $\approx 690 \mathrm{Wh} / \mathrm{kg}_{\text {LNMO }}{ }^{2}$ is an interesting alternative for Co-free LithiumIon batteries. However, graphite/LNMO cells do suffer from a drastic capacity decay when cycled at elevated temperatures $\left(>40^{\circ} \mathrm{C}\right),{ }^{3-5}$ which is related to electrochemical electrolyte oxidation ${ }^{6}$ followed by transition metal dissolution (both manganese and nickel) from the spinel cathode, ${ }^{5,7}$ ultimately leading to a loss of active lithium on the graphite anode due to ongoing SEI formation. ${ }^{3,5}$ As the degradation of the graphite anode is a key failure mechanism of graphite/LNMO cells, a detailed impedance analysis of the anode in graphite/LNMO full-cells is necessary to better understand this degradation process, particularly at elevated temperatures.

In the literature, there are several approaches in order to investigate the anode impedance. One type of studies focuses on the solid electrolyte interface (SEI) formation on graphite anodes and model setups in order to investigate the formation of the SEI. ${ }^{8-11}$ The impedance is recorded at different potentials during lithiation of a graphite anode and the impedance response is generally fitted with two $\mathrm{R} / \mathrm{C}$ (resistor/capacitor) or R/Q (resistor/constant phase element) elements connected in series, representing the charge transfer resistance and the SEI resistance. In these studies the graphite impedance is measured versus the lithium metal counter electrode in a two-electrode configuration, despite the fact that the lithium metal anode dominates the EIS response due to its small surface area ${ }^{12}$ and thus obviously prevents a rigorous analysis of the graphite electrode impedance. Another type of studies uses a symmetric cell approach in order to deconvolute the anode impedance from the full-cell impedance. ${ }^{13,14}$ However, as the symmetric cell approach is a destructive method, the determination of the anode (or cathode) impedance as a function of the number of charge/discharge cycles or of the state-of-charge (SOC) requires the testing/cycling of a large number of cells. A third group of papers uses micro-reference electrodes, where a deconvolution of

\footnotetext{
$=$ These authors contributed equally to this work

* Electrochemical Society Student Member.

***Eectrochemical Society Fellow.

${ }^{\mathrm{z}}$ E-mail: j.landesfeind@tum.de
}

the anode impedance from the full-cell impedance is possible during cycling without disassembly of the cells (contrary to the symmetric cell approach). ${ }^{12,15,16}$ Here the reference electrode has to fulfill certain criteria, as for example being centered between two separators ${ }^{17}$ and being thin relative to the separator thickness. ${ }^{18}$ Yet, also the deconvolution into separate impedances for anode and cathode do not suffice to fully understand the origin of the anode impedance buildup as the characteristic frequencies overlap. In summary, in order to quantify the evolution of the impedance of an individual electrode with cycle number and/or SOC in the absence/presence of additives, either a micro-reference electrode must be incorporated or the more cumbersome symmetric cell approach must be used.

In a previous study of our group ${ }^{19}$ we analyzed the impedance of an LNMO cathode in graphite/LNMO full-cells, where we introduced a new method based on determining the LNMO impedance in nonblocking conditions (i.e., at $\approx 4.4 \mathrm{~V}$ cell voltage $(\approx 10 \%$ SOC) under open-circuit conditions) and in blocking conditions (i.e., holding the cell voltage at $4.9 \mathrm{~V}$ cell at $100 \%$ SOC) utilizing a micro-reference electrode $\left(\mathrm{GWRE}^{12}\right)$. We were able to deconvolute the total LNMO cathode impedance $\left(R_{\text {Cathode }}\right)$ evolving over 86 charge/discharge cycles into contributions of: (i) a contact resistance between the current collector and the LNMO electrode $\left(R_{\text {Cont. }}\right)$, (ii) the true LNMO charge transfer resistance $\left(R_{\mathrm{CT}}\right)$, and, (iii) the ionic resistance of the electrolyte within the LNMO cathode pores $\left(R_{\text {Pore }}\right)$. This deconvolution was possible, as from the spectrum in blocking conditions (i.e., in the absence of faradaic reactions, as the cathode does not contain lithium) the pore resistance could be obtained unambiguously from the $45^{\circ}$ transmission line feature, clearly separated in frequency space from the charge transfer resistance feature, which under this condition is shifted to very low frequencies in the impedance spectrum. By simultaneously fitting both the blocking and non-blocking spectra with a general transmission line model (TLM), a deconvolution of the various above described resistance contributions with very low uncertainties was possible.

Here we will apply our impedance analysis concept to study the impedance evolution of a graphite anode in a full-cell over extended charge/discharge cycling. Our approach will be to measure the impedance of the graphite anode either in a graphite/LFP cell or in a graphite/LNMO cell at low full-cell voltages $(\approx 1.7-1.9 \mathrm{~V}$ vs. 
$\mathrm{Li} / \mathrm{Li}^{+}$) where the graphite anode in the cell is in its fully delithiated state, demonstrating that blocking electrode behavior can be achieved for the graphite anode. Over the course of 86 charge/discharge cycles of a graphite/LNMO full-cell at $40^{\circ} \mathrm{C}$, we observe the appearance of a high-frequency semi-circle in the graphite blocking impedance spectra, which we will ascribe to the formation of a resistive region at the anode/separator interface, likely induced by manganese dissolution from the cathode. Further insights into the evolving anode impedance in a graphite/LNMO full-cell will be gained by simultaneously fitting the impedance spectra for a given cycle to a general transmission line model under both blocking conditions (at a full-cell voltage of $3.0 \mathrm{~V}_{\mathrm{FC}}$, i.e., when graphite is fully delithiated) and non-blocking conditions (at $4.4 \mathrm{~V}_{\mathrm{FC}}$, i.e., when graphite is partially lithiated), which enables us to clearly deconvolute the overall anode impedance. Last, we will show the overall impedance of a graphite/LNMO full-cell and provide a detailed analysis of the various impedance contributions from anode and cathode over the course of extended charge/discharge cycling at $40^{\circ} \mathrm{C}$.

\section{Experimental}

Electrode preparation.- $\mathrm{LiNi}_{0.5} \mathrm{Mn}_{1.5} \mathrm{O}_{4}$ (LNMO) electrodes were prepared by mixing LNMO (BASF SE, Germany), carbon black (Super C65, Timcal), and polyvinylene difluoride (PVdF, Kynar) at a mass ratio of 92/5/3 with NMP (N-methyl pyrrolidone, anhydrous, Sigma-Aldrich, Germany) in a planetary mixer (Thinky Corp.) for $15 \mathrm{~min}$. The ink was coated onto aluminum foil (MTI, $18 \mu \mathrm{m}$ ) with a doctor blade coater and dried afterwards at $50^{\circ} \mathrm{C}$ in a convection oven for at least $3 \mathrm{~h}$. The final LNMO coating had a loading of $\approx 13.6 \mathrm{mg}_{\mathrm{LNMO}} / \mathrm{cm}^{2}$, corresponding to $\approx 1.9 \mathrm{mAh} / \mathrm{cm}^{2}$. Electrodes with a diameter of $11 \mathrm{~mm}\left(\equiv 0.95 \mathrm{~cm}^{2}\right)$ were punched out and compressed to $\approx 32 \%$ porosity with a $\mathrm{KBr}$ press (Mauthe, PE011). $\mathrm{LiFePO}_{4}$ (LFP) electrodes with a mass ratio of 93/4/3 (LFP/PVdF/carbon black) were prepared using the same mixing- and coating procedure as for the LNMO cathodes. The final loading was $\approx 16.5 \mathrm{mg} \mathrm{LFP}_{\mathrm{LP}} / \mathrm{cm}^{2}$, corresponding $\approx 2.0 \mathrm{mAh} / \mathrm{cm}^{2}$, and the cathodes (11 mm diameter) were compressed to a porosity of $30 \%$.

Graphite electrodes were prepared by mixing graphite (T311, SGL Carbon, Germany) and PVdF at a mass ratio of 95/5 with NMP by applying the same procedure as for the positive electrodes. The graphite ink was coated onto copper foil (MTI, $\sim 12 \mu \mathrm{m}$ ) and dried in a convection oven at $50^{\circ} \mathrm{C}$ for $3 \mathrm{~h}$. The loading of the graphite coating was $\approx 6.6 \mathrm{mg}_{\text {graphite }} / \mathrm{cm}^{2}$ corresponding to $\approx 2.3 \mathrm{mAh} / \mathrm{cm}^{2}$. The electrodes were punched out with a diameter of $11 \mathrm{~mm}$ and compressed to a porosity of $\approx 32 \%$. All electrodes were dried under dynamic vacuum at $120^{\circ} \mathrm{C}$ for at least $12 \mathrm{~h}$ in a vacuum oven (Büchi, Switzerland) and then transferred into an Argon-filled glove box (MBraun, Germany) without exposure to air.

Cell assembly and battery testing.-T-cells (Swagelok, U.S) were assembled in an Argon-filled glove box $\left(<0.1\right.$ ppm $\mathrm{O}_{2}$ and $\mathrm{H}_{2} \mathrm{O}$, MBraun, Germany) and dried beforehand in a $70^{\circ} \mathrm{C}$ convection oven. The graphite anode and the LNMO or LFP cathodes were assembled into a cell with two glass fiber separators (glass microfiber filter, 691, VWR Germany). As electrolyte, $60 \mu \mathrm{L}$ of LP57 (1 M LiPF in EC/EMC 3:7 w:w $<20$ ppm $\mathrm{H}_{2} \mathrm{O}$, BASF SE, Germany) were used. Between the separators a gold wire micro-reference electrode (GWRE) was placed (the detailed assembly procedure can be found in Reference 12). The GWRE was lithiated in the fully assembled cell with a constant current of $150 \mathrm{nA}$ for $1 \mathrm{~h}$ at $40^{\circ} \mathrm{C}$ (note that the amount of lithium provided by the cathode for charging of the GWRE $(0.15 \mu \mathrm{Ah})$ is negligible compared to the total lithium inventory $(\approx 1.9 \mathrm{mAh}))$. While the pure noble metal gold wire is not a suitable reference electrode for the lithium ion containing organic electrolytes, the in-situ lithiation forms a lithium-gold alloy with a very stable potential of $\approx 0.31 \mathrm{~V}$ versus metallic lithium. ${ }^{12}$ In the present study, the transition metal dissolution from the cathode leads to a gradual delithiation of the lithiated GWRE. Although the GWRE can be lithiated again ${ }^{20}$ to obtain a good reference electrode, in the present

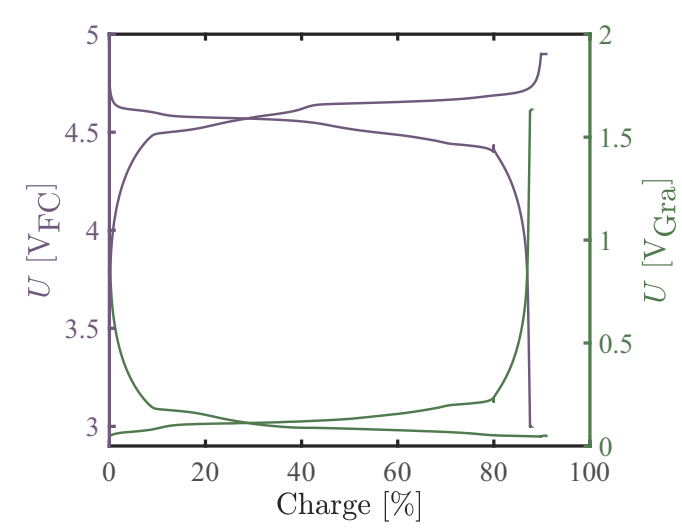

Figure 1. Charge/discharge potential profiles of the first cycle at $\mathrm{C} / 2$ (after formation) of a $\mathrm{LNMO} / g$ raphite cell at $40^{\circ} \mathrm{C}$ equipped with a lithium reference electrode. The graphite anode potential is shown in green color with the corresponding right y-axis, while the potentials of the cathode is depicted by the left hand y-axis. Impedance spectra were recorded at the end of charge/discharge in blocking condition as well as after the full-cell potential of the LNMO/graphite cell reached $4.4 \mathrm{~V}$ after one hour of OCV phase.

study the GWRE is only used as a pseudo reference (i.e., only for EIS measurements not for referencing potentials). Due to the electrochemical electrolyte oxidation on LNMO cathodes, protic species and other electrolyte oxidation fragments are produced ${ }^{21}$ which apparently cause a gradual delithiation of the lithiated GWRE, leading to a loss of its stable reference potential after several cycles. ${ }^{20}$ However, as shown in Part I of this publication, ${ }^{19}$ the potential drift of the GWRE is smaller than $<0.4 \mathrm{mV}$ over the course of a full impedance measurement, and hence this drift does not affect the EIS measurements with an AC perturbation of $15 \mathrm{mV}$. This means that over cycling the lithiated GWRE acts as a pseudo-reference electrode with an undefined potential. In order to convert the full-cell potential (graphite/LNMO) into a half-cell potential (graphite/Li) identical T-cells were assembled with a lithium metal reference electrode.

The cycling procedure is identical to the cells cycled in Reference 19. The full-cells (graphite/LNMO) were cycled between 3.0 and $4.9 \mathrm{~V}_{\mathrm{FC}}$ (full cell voltage). Two formation cycles were carried out at $25^{\circ} \mathrm{C}$ with a C-rate of $\mathrm{C} / 10(1 / \mathrm{h})$ by applying a CCCV charge (constant current followed by a constant voltage) with a current limit of $\mathrm{C} / 20$ for the $\mathrm{CV}$ phase as well as a $\mathrm{CC}$ discharge. The subsequent extended charge/discharge cycling was carried out with $\mathrm{C} / 2$ at $40^{\circ} \mathrm{C}$ with a CCCV charge to $4.9 \mathrm{~V}_{\mathrm{FC}}$ (current limit for $\mathrm{CV}=\mathrm{C} / 40$ ) and a CCCV discharge to $3.0 \mathrm{~V}_{\mathrm{FC}}$ (current limit for $\mathrm{CV}=\mathrm{C} / 100$ ); the $\mathrm{CV}$ step at the end of discharge is required to bring the graphite anode into blocking conditions. The impedance was recorded at OCV (open circuit voltage) in non-blocking conditions at $4.4 \mathrm{~V}_{\mathrm{FC}}$ after a $1 \mathrm{~h}$ OCV period as well as in blocking conditions at $3.0 \mathrm{~V}_{\mathrm{FC}}\left(\mathrm{E}_{\mathrm{Gra}} \approx\right.$ $1.7 \mathrm{~V}_{\mathrm{Li}}$ ) during a constant voltage hold and after the current had dropped below $\mathrm{C} / 100$. The impedance was recorded from $100 \mathrm{kHz}$ to $100 \mathrm{mHz}$ with a perturbation of $15 \mathrm{mV}$ (acquisition time of $10 \mathrm{~min} / \mathrm{spectrum})$. Figure 1 shows the graphite/LNMO full cell potential (in purple) and the graphite versus metallic lithium potential (in green) during charge and discharge $\left(\mathrm{C} / 2\right.$ at $\left.40^{\circ} \mathrm{C}\right)$.

Graphite/LNMO cells for reaching blocking conditions were conditioned the following (data shown in Figure 2): Formation ( 2 cycles at $\mathrm{C} / 10$ and $25^{\circ} \mathrm{C}$ ) was carried out and afterwards the cell was charged to the upper cutoff potential of $4.9 \mathrm{~V}_{\mathrm{FC}}\left(\right.$ at $\mathrm{C} / 2$ and $\left.40^{\circ} \mathrm{C}\right)$ and during the subsequent discharge $\left(3 \mathrm{~min}\right.$ at $\mathrm{C} / 20$ and $40^{\circ} \mathrm{C}$ ) the impedance was recorded under open-circuit potential. Once the lower cell cutoff potential of $3.0 \mathrm{~V}_{\mathrm{FC}}\left(\mathrm{E}_{\mathrm{Gra}} \approx 1.7 \mathrm{~V}_{\mathrm{Li}}\right)$ was reached the impedance was measured around this potential.

Graphite/LFP cells were also equipped with a GWRE and two formation cycles were carried out at $\mathrm{C} / 10$ at $25^{\circ} \mathrm{C}$ with a $\mathrm{CCCV}$ charge to $4.0 \mathrm{~V}_{\mathrm{FC}}$ (current limit of $\mathrm{C} / 20$ ) and a $\mathrm{CC}$ discharge to $2.0 \mathrm{~V}_{\mathrm{FC}}$. After formation, five cycles at $\mathrm{C} / 2$ and $40^{\circ} \mathrm{C}$ from $1.5 \mathrm{~V}_{\mathrm{FC}}$ 


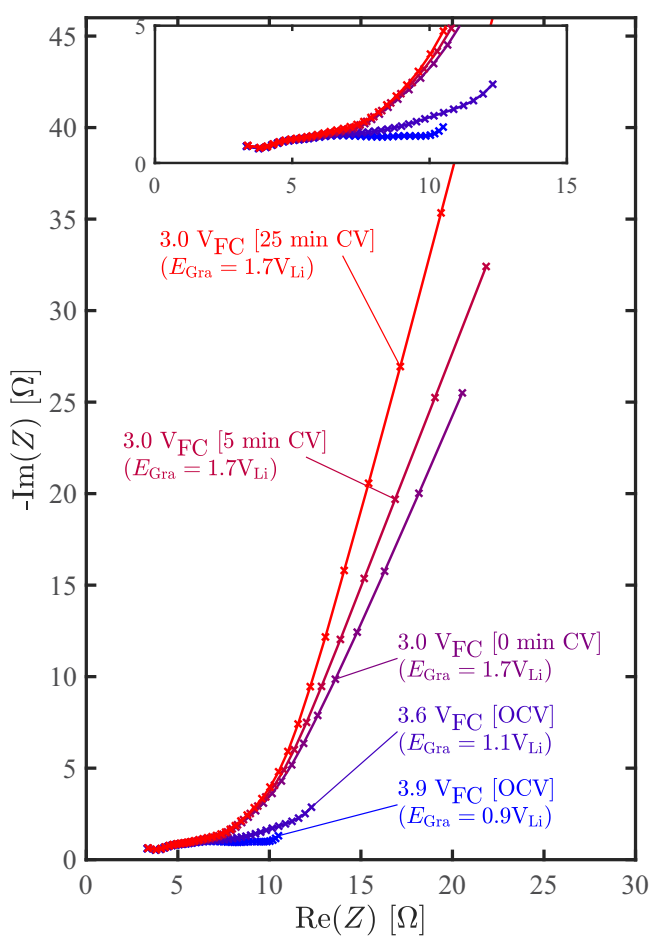

Figure 2. Graphite anode impedance spectra measured with a micro-reference electrode (GWRE) in a graphite/LNMO cell. The impedance spectra shown at 3.9, 3.6, and 3.0 $\mathrm{V}_{\mathrm{FC}}$ are recorded under open circuit conditions (labeled as [OCV]) and those at $3.0 \mathrm{~V}_{\mathrm{FC}}$ while holding a constant voltage (CV-hold) for either 5 or 25 minutes (labeled as [\# min CV]). The graphite potentials vs. $\mathrm{Li} / \mathrm{Li}^{+}\left(E_{\mathrm{Gra}}\right)$ are also shown by the graph labels; the values were obtained from measurements conducted in an identical T-cell equipped with a lithium metal reference electrode flag. The impedance is recorded at $40^{\circ} \mathrm{C}$ from $100 \mathrm{kHz}$ to $100 \mathrm{mHz}$ with a perturbation of $15 \mathrm{mV}$.

and $4.0 \mathrm{~V}_{\mathrm{FC}}$ were conducted and the impedance was recorded at $1.5 \mathrm{~V}_{\mathrm{FC}}\left(\mathrm{E}_{\mathrm{Gra}} \approx 1.87 \mathrm{~V}_{\mathrm{Li}}\right)$ under constant voltage conditions, after the current dropped below $\mathrm{C} / 100$.

For the cells reaching blocking conditions for a graphite anode cycled versus LFP (data shown in Figure 3 ) the following procedure was used: After two formation cycles at $\mathrm{C} / 10$ and $25^{\circ} \mathrm{C}$ and one charge to $4.0 \mathrm{~V}$ cell voltage $\left(\mathrm{C} / 2\right.$ and $\left.40^{\circ} \mathrm{C}\right)$, the graphite/LFP cell was discharged $(\mathrm{C} / 20$, delithiation of the graphite anode) and impedance spectra were recorded every $2 \mathrm{~min}$ in open circuit condition and after 0 and 5 minutes of $\mathrm{CV}$ phase when the potential reached $1.5 \mathrm{~V}_{\mathrm{FC}}$ $\left(\mathrm{E}_{\mathrm{Gra}} \approx 1.87 \mathrm{~V}_{\mathrm{Li}}\right)$.

As electrolyte, $60 \mu \mathrm{L}$ of either LP57 $\left(1 \mathrm{M} \mathrm{LiPF}_{6}\right.$ in EC/EMC 3:7 w:w $<20 \mathrm{ppm} \mathrm{H}_{2} \mathrm{O}$, BASF SE, Germany) or LP57 with 50 or $100 \mathrm{mM}$ $\mathrm{Mn}(\mathrm{TFSI})_{2}$ (Solvionic, France) were used.

\section{Results and Discussion}

Blocking conditions for a graphite anode cycled vs. LFP or LNMO at $\mathbf{4 0}$ C.- In Part I of this study, ${ }^{19}$ we successfully deconvoluted the impedance contributions from contact resistance $\left(R_{\text {Cont. }}\right)$, porous electrode resistance $\left(R_{\text {Pore }}\right)$, and charge transfer resistance $\left(R_{\mathrm{CT}}\right)$ of an LNMO cathode by simultaneous analysis of recorded impedance spectra in blocking and non-blocking configuration for the LNMO cathode. To apply this technique to a graphite anode (or any electrode for this matter), it is necessary to check if blocking conditions can be obtained. Blocking conditions imply that the charge transfer reaction resistance is getting very large (ideally infinite), so that the corresponding impedance feature will be moved to very low frequencies, which allows for an unambiguous interpretation of the remaining impedance contributions.

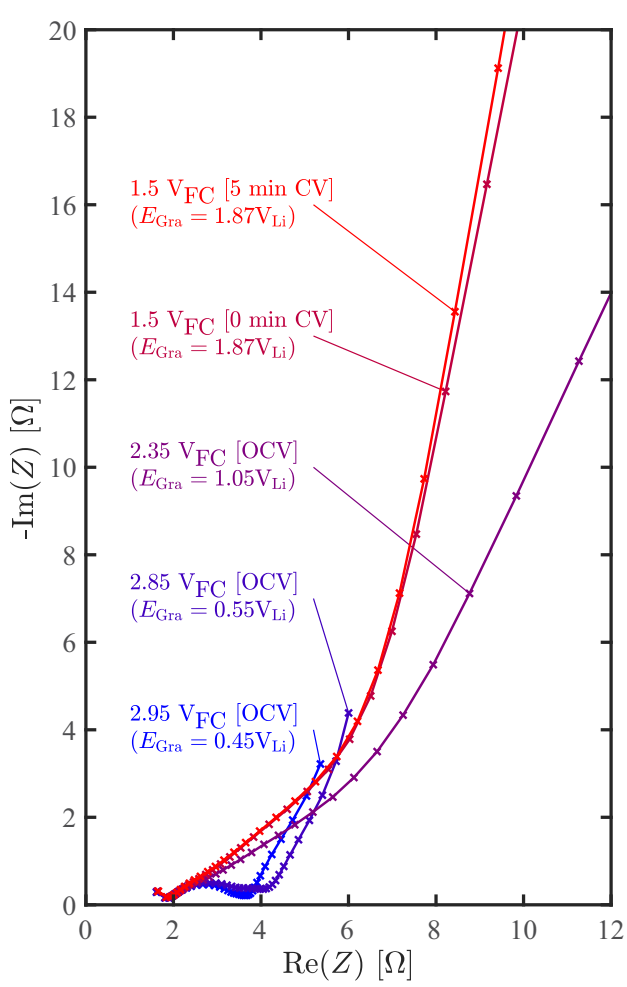

Figure 3. Graphite anode impedance spectra measured with a micro-reference electrode (GWRE) in a graphite/LFP cell. The impedance spectra shown at $2.95,2.85$, and $2.35 \mathrm{~V}_{\mathrm{FC}}$ are recorded under open circuit conditions (labeled as [OCV]), and those at $1.5 \mathrm{~V}_{\mathrm{FC}}$ are recorded while holding a constant potential (CV-hold) for either 0 or 5 minutes (labeled as [\# min CV]). The graphite potentials vs. $\mathrm{Li} / \mathrm{Li}^{+}\left(E_{\mathrm{Gra}}\right)$ is also shown by the graph labels; its values were obtained from the GWRE (see text). The impedance is recorded at $40^{\circ} \mathrm{C}$ from $100 \mathrm{kHz}$ to $100 \mathrm{mHz}$ with a perturbation of $15 \mathrm{mV}$.

To check at which potentials blocking conditions of the graphite anode can be reached in a full-cell, a graphite/LNMO cell with a gold wire micro-reference electrode (GWRE) was assembled and two formation cycles were done at $\mathrm{C} / 10$ at $25^{\circ} \mathrm{C}$. Afterwards the cell was charged to the upper cutoff potential of $4.9 \mathrm{~V}_{\mathrm{FC}}$ cell voltage (at $\mathrm{C} / 2$ and $40^{\circ} \mathrm{C}$ ) and during the subsequent discharge steps (each $3 \mathrm{~min}$ at $\mathrm{C} / 20$ and $40^{\circ} \mathrm{C}$ ) the impedance was recorded under open-circuit potential. Once the lower cell cutoff potential of $3.0 \mathrm{~V}_{\mathrm{FC}}$ was reached the impedance was measured around this potential. The spectra are shown in Figure 2. At $3.9 \mathrm{~V}_{\mathrm{FC}}$, which corresponds to a graphite potential of $\approx 0.9 \mathrm{~V}$ vs. $\mathrm{Li} / \mathrm{Li}^{+}$, the impedance spectrum conducted at $\mathrm{OCV}$ consists of a suppressed semi-circle and a $45^{\circ}$ Warburg branch (blue line). During subsequent discharge of the full-cell (nearly complete delithiation of the anode) to $3.6 \mathrm{~V}_{\mathrm{FC}}$ (graphite at $\approx 1.1 \mathrm{~V} \mathrm{vs.} \mathrm{Li} / \mathrm{Li}^{+}$) and $3.0 \mathrm{~V}_{\mathrm{FC}}$ (graphite at $\approx 1.7 \mathrm{~V}$ vs. $\mathrm{Li} / \mathrm{Li}^{+}$), the impedance spectra taken at OCV show a significant increase of the imaginary part of the impedance at low frequencies, which indicates a significantly increased charge transfer resistance. When the cell potential is held at $3.0 \mathrm{~V}_{\mathrm{FC}}$ (graphite at $\approx 1.7 \mathrm{~V} \mathrm{vs}$. $\mathrm{Li} / \mathrm{Li}^{+}$) for $5 \mathrm{~min}$. (dark red line) or $25 \mathrm{~min}$., lithium reintercalation into the graphite anode is completely suppressed, as can be seen from the now nearly vertical straight line at low frequencies, i.e., blocking conditions are achieved. At the same time, at medium frequencies a $45^{\circ}$ transmission line can be observed in Figure 2, from which the ionic resistance within the porous graphite $\left(R_{\text {Pore }}\right)$ anode can be determined. ${ }^{22}$ The points at the lowest measured frequencies $(100 \mathrm{mHz})$ shift toward higher values on the (negative) imaginary axis with increasing length of the constant voltage phase, which is analogous to what was observed when putting an LNMO cathode under blocking conditions. ${ }^{19}$ At high frequencies (left in the Nyquist plot), a strongly depressed semi-circle is present in the anode blocking spectra (see inset of Figure 2). This suppressed semi-circle is 
already apparent directly after formation of the LNMO/graphite cells and will be analyzed in detail below.

To investigate whether the anode impedance depends on the cathode active material via a cross-talk mechanism, ${ }^{23}$ the above experiments were repeated with a graphite/LFP full-cell. After two formation cycles at $\mathrm{C} / 10$ and $25^{\circ} \mathrm{C}$ and one charge to $4.0 \mathrm{~V}$ cell voltage $(\mathrm{C} / 2$ and $\left.40^{\circ} \mathrm{C}\right)$, the graphite/LFP cell was discharged $(\mathrm{C} / 20$, delithiation of the graphite anode) and impedance spectra were recorded every $2 \mathrm{~min}$ in open circuit condition and after 0 and 5 minutes of $\mathrm{CV}$ phase when the potential reached $1.5 \mathrm{~V}_{\mathrm{FC}}$. Figure 3 shows the anode impedance spectra of a graphite/LFP cell measured at different voltages. The potential versus metallic lithium $\left(\mathrm{V}_{\mathrm{Li}}\right)$ was obtained from the known potential of the lithiated GWRE $\left(\approx 0.31 \mathrm{~V}\right.$ vs. $\left.\mathrm{Li} / \mathrm{Li}^{+}\right)$, which for an LFP cathode remained stable over hundreds of cycles. ${ }^{12}$ At a graphite potential of $0.45 \mathrm{~V}_{\mathrm{Li}}(\approx 70 \%$ SOC $)$ and $0.55 \mathrm{~V}_{\mathrm{Li}}(\approx 80 \%$ SOC $)$, the impedance spectrum consists of one suppressed semi-circle, which includes contributions from both the charge transfer resistance and the SEI resistance $\left(R_{\mathrm{CT}}\right.$ and $\left.R_{\mathrm{SEI}}\right)$ as well as of a $45^{\circ}$ Warburg diffusion branch representing lithium ion concentration gradients within the separator. By further delithiating the graphite anode (see spectrum at $1.05 \mathrm{~V}_{\mathrm{Li}}$ ) the semi-circle turns into $\mathrm{a} \approx 40^{\circ}$ line and the points at lower frequencies show the typical onset of the transition into blocking conditions, as at $1.05 \mathrm{~V}_{\mathrm{Li}}$ lithium reintercalation into graphite becomes thermodynamically unfavorable. By going to a graphite potential of $1.87 \mathrm{~V}_{\mathrm{Li}}$, i.e., to a similar high anode potential at which blocking conditions were observed for the graphite/LNMO cell (see spectra at $1.7 \mathrm{~V}$ vs. $\mathrm{Li} / \mathrm{Li}^{+}$in Figure 2), the graphite anode impedance spectra after 0 and 5 minutes $\mathrm{CV}$ phase also show a blocking electrode behavior, as one would expect. However, for the graphite anode in a graphite/LFP cell (see Figure 3 ) the $45^{\circ}$ transmission line region is clearly pronounced and unperturbed up to the highest measured frequency $(100 \mathrm{kHz})$, while for the same procedure the graphite impedance in the graphite/LNMO cells shows a depressed semicircle at high frequencies (see inset in Figure 2). The origin of this difference will be examined further below. Please note that a cutoff in the graphite/LNMO cell of $3.0 \mathrm{~V}_{\mathrm{FC}}$ gives an anode potential of $\approx 1.7 \mathrm{~V}$ vs. $\mathrm{Li} / \mathrm{Li}^{+}$and a cutoff in the graphite/LFP cell of $1.5 \mathrm{~V}_{\mathrm{FC}}$ an anode potential of $\approx 1.87 \mathrm{~V} \mathrm{vs}$. $\mathrm{Li} / \mathrm{Li}^{+}$. As the graphite potential is very steep starting from $1.0 \mathrm{~V} \mathrm{vs}$. $\mathrm{Li} / \mathrm{Li}^{+}$(see Figure 1) we are sure that both anode potentials (from the LNMO and LFP cells) are well comparable.

Graphite impedance evolution over charge/discharge cycling of graphite/LNMO cells at $40^{\circ}$ C.- - In the following section, we want to analyze both blocking and non-blocking impedance spectra of a graphite anode in a graphite/LNMO full-cell over the course of 86 charge/discharge cycles and investigate the evolution of the suppressed semi-circle at higher frequencies with cycling (a feature which above was shown to be absent when cycling a graphite anode with an LFP cathode). The cycle dependent Nyquist plots for the anode under non-blocking (at $4.4 \mathrm{~V}_{\mathrm{FC}}$ corresponding to $\approx 10 \% \mathrm{SOC}$, Figure 4a) and blocking conditions (the current dropped below $\mathrm{C} / 100$ during the $\mathrm{CV}$ phase at $3.0 \mathrm{~V}_{\mathrm{FC}}$, Figure $4 \mathrm{~b}$ ) are shown for the $1^{\text {st }}, 25^{\text {th }}$, $50^{\text {th }}$ and $75^{\text {th }}$ cycle at $\mathrm{C} / 2\left(\equiv 0.95 \mathrm{~mA} / \mathrm{cm}^{2}\right)$ and $40^{\circ} \mathrm{C}$. The capacity retention of this cell is shown in Figure 4 of Part I of this study. ${ }^{19}$ For the spectra in non-blocking conditions (Figure 4a)), the impedance spectrum consists of the separator resistance (high-frequency resistance, HFR) and a semi-circle, which is a convolution of the charge transfer resistance, the SEI resistance, and the pore resistance. At lowest frequencies, a $45^{\circ}$ line for the Warburg diffusion is observable. The diameter of the semi-cirlce increases from $\approx 2 \Omega \mathrm{cm}^{2}$ (cycle 1 after formation) to $\approx 15 \Omega \mathrm{cm}^{2}$ (cycle 75 afterformation). The capacitance obtained from a constant-phase element (Q) fit after 25 cycles is $8.9 \mathrm{mF} \cdot \mathrm{s}^{\left(\alpha_{\mathrm{CT}}-1\right)} / \mathrm{cm}_{\text {geo. }}^{2}$ (normalized to the geometric area of the electrode), with the constant-phase element exponent value of $\alpha_{\mathrm{CT}} \approx 0.75$. To a first order approximation, this can be approximated with a real capacitance of $8.9 \mathrm{mF} / \mathrm{cm}_{\text {geo. }}^{2}$; if referenced to the roughness factor of the graphite anode $\left(30 \mathrm{~cm}^{2}{ }_{\mathrm{BET}} / \mathrm{mg}_{\text {graph }} \times 6.6 \mathrm{mg}_{\text {graph. }} / \mathrm{cm}^{2}\right.$ geo. $\approx 200 \mathrm{~cm}^{2}{ }_{\text {BET }} / \mathrm{cm}^{2}{ }_{\text {geo. }}$ ), this yields a BET surface normalized capac-
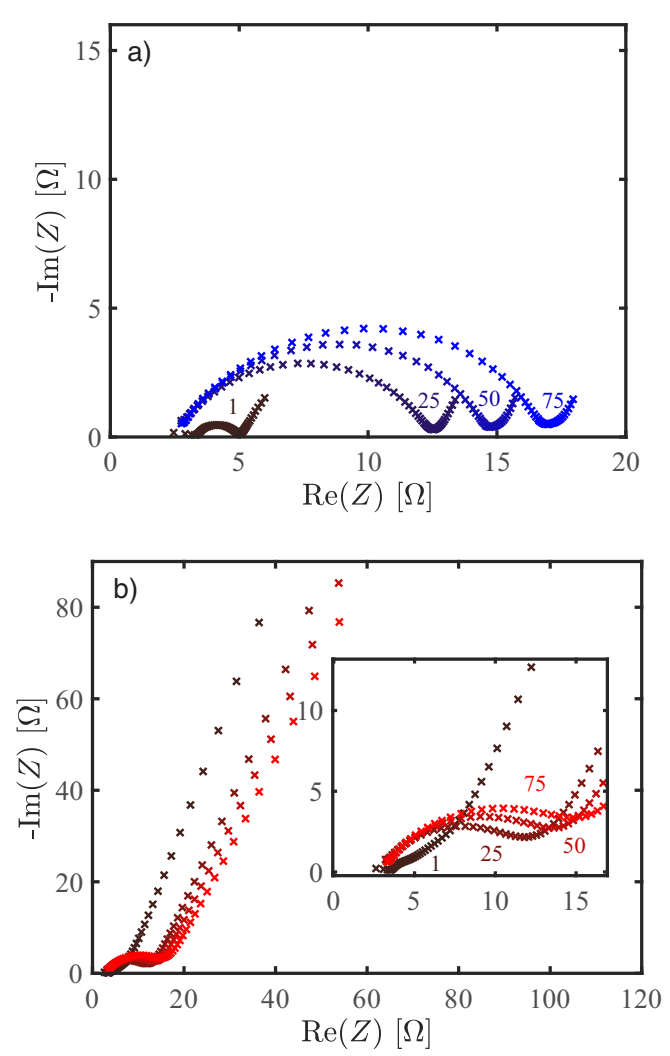

Figure 4. Evolution of the impedance spectra of the graphite anode (cycle numbers $1,25,50$ and 75 as marked in the figure) during cycling of an $\mathrm{LNMO}$ /graphite cell at a rate of $\mathrm{C} / 2$ at $40^{\circ} \mathrm{C}$ : a) at $4.4 \mathrm{~V}_{\mathrm{FC}}$ in non-blocking conditions at $10 \%$ SOC (EIS recorded at OCV after $1 \mathrm{~h} \mathrm{OCV} \mathrm{period);} \mathrm{b)} \mathrm{after}$ a potential hold at $3.0 \mathrm{~V}_{\mathrm{FC}}$ under blocking conditions at $100 \% \mathrm{SOC}$ (recorded at a controlled potential of $3.0 \mathrm{~V}_{\mathrm{FC}}$ after a potential hold at $3.0 \mathrm{~V}_{\mathrm{FC}}$ until the current dropped below C/100). Potential controlled EIS spectra were recorded with an amplitude of $15 \mathrm{mV}$ in the frequency range from $100 \mathrm{kHz}$ to $100 \mathrm{mHz}$.

itance of $\approx 4.5 \mu \mathrm{F} / \mathrm{cm}_{\mathrm{BET}}^{2}$, which is reasonably consistent with the electrochemical double-layer capacitance of graphite. In consequence the semi-circle observed in non-blocking conditions results from a resistance occurring everywhere in the graphite anode.

The blocking spectra (Figure 4b) show a slightly distorted transmission line after the first cycle (convolution of a semi-circle at high frequencies and a $45^{\circ}$ line at medium frequencies), followed by the onset of a very large charge transfer resistance which indicates blocking behavior. After 25 cycles, the blocking spectra show a distinct semi-circle with a diameter of $\approx 10 \Omega \mathrm{cm}^{2}$, which increases to $\approx 15 \Omega \mathrm{cm}^{2}$ after 75 cycles. A semi-circle under blocking conditions (no faradaic process during the impedance measurement) has so far only been observed if there is a contact resistance $\left(R_{\text {Cont. }}\right)$ between an aluminum current collector and a cathode coating. ${ }^{19,24,25}$ However, for a graphite anode coated on a copper collector - both materials being excellent electronic conductors - we do not expect a contact resistance between the current collector and the anode coating. Also, in graphite/LFP cells cycled at $40^{\circ} \mathrm{C}$ (data not shown in here), no semi-circle evolves in the graphite anode blocking spectra. Further insights might be gained by examining the capacitance associated with this semi-circle. Its constant-phase capacitance after the $25^{\text {th }}$ cycle is $\approx 73 \mu \mathrm{F} \cdot \mathrm{s}^{\left(\alpha_{\text {blocking }}-1\right)} / \mathrm{cm}_{\text {geo. }}^{2}$ (with $\alpha_{\text {blocking }} \approx 0.74$ ), which is two orders of magnitude lower compared to the semi-circle capacitance in the respective non-blocking spectrum discussed above. If this value was used to estimate the double-layer capacitance of the graphite surface as done above, this would yield a double-layer capacitance of $0.4 \mu \mathrm{F} / \mathrm{cm}_{\mathrm{BET}}^{2}$, which clearly is too low and suggests that this resistance dervives from only a fraction of $\approx 10 \%$ of that of the entire graphite area, e.g., only from a layer of the anode which corresponds 


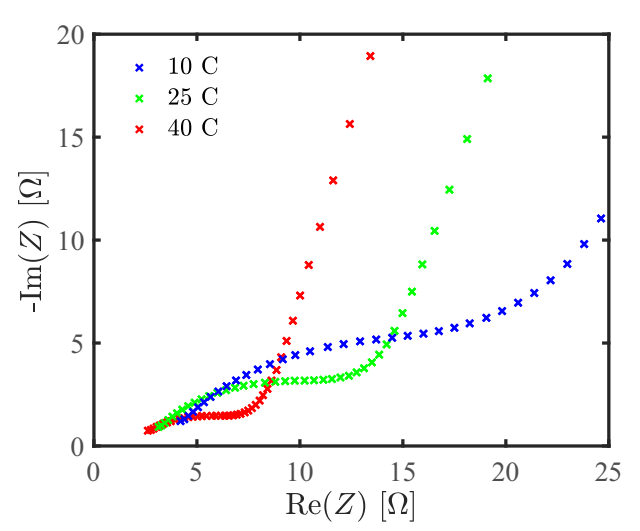

Figure 5. Impedance spectra of a graphite anode measured versus the GWRE in a graphite/LNMO cell after formation (two cycles at $\mathrm{C} / 10$ and $25^{\circ} \mathrm{C}$ ) and 5 cycles at $\mathrm{C} / 2\left(40^{\circ} \mathrm{C}\right)$. The impedance is recorded at $10^{\circ} \mathrm{C}, 25^{\circ} \mathrm{C}$ and $40^{\circ} \mathrm{C}$ in blocking conditions $\left(3.0 \mathrm{~V}_{\mathrm{FC}}\right.$ potential hold after a $\mathrm{CV}$ phase at $3.0 \mathrm{~V}_{\mathrm{FC}}$ with a current limit of $\mathrm{C} / 100$ ). The impedance is measured from $100 \mathrm{kHz}$ to $100 \mathrm{mHz}$ with a perturbation of $15 \mathrm{mV}$. Before starting the measurement, an open-circuit period $(1 \mathrm{~h})$ at the specific temperature is carried out to ensure thermal equilibration.

to $\approx 10 \%$ of its thickness. It is emphasized that a similar double layer capacitance as in non-blocking conditions $\left(\approx 4.5 \mu \mathrm{F} / \mathrm{cm}_{\mathrm{BET}}^{2}\right)$ would be expected in blocking conditions if the origin of the resistance would occur everywhere in the graphite anode. A possible explanation for the localized effect might be type of high-resistance region at the toplayer of the anode adjacent to the separator which was suggested by Burns et al. ${ }^{26}$ In the next section, we will further examine the origin for this semi-circle in the graphite anode blocking impedance spectra.

Origin of the high frequency semi-circle in the graphite impedance spectra under blocking conditions in graphite/LNMO cells.-In order to elucidate the physical origin of the high frequency semi-circle in blocking conditions (Figure $4 \mathrm{~b}$ ), temperature-dependent EIS measurements of a graphite/LNMO cell with a GWRE were recorded in blocking conditions $\left(3.0 \mathrm{~V}_{\mathrm{FC}}\right.$ ) after formation (two $\mathrm{C} / 10$ cycles at $25^{\circ} \mathrm{C}$ ) and five subsequent $\mathrm{C} / 2$ charge/discharge cycles at $40^{\circ} \mathrm{C}$. The impedance was measured at $10^{\circ} \mathrm{C}$ (blue points), at $25^{\circ} \mathrm{C}$ (green points), and at $40^{\circ} \mathrm{C}$ (red points) in order to discriminate its origin to be of electronic or ionic nature (see Figure 5). The diameter of the suppressed semi-circle increases from $\approx 9 \Omega \mathrm{cm}^{2}$ at $40^{\circ} \mathrm{C}$ to $\approx 14 \Omega \mathrm{cm}^{2}$ at $25^{\circ} \mathrm{C}$ and $\approx 22 \Omega \mathrm{cm}^{2}$ at $10^{\circ} \mathrm{C}$. From this data, the apparent activation energy is calculated using the Arrehnius equation. A similar analysis examining several types of resistances occuring in porous electrodes was done by Ogihara et al. ${ }^{27}$ We find an apparent activation energy of $\approx 9 \mathrm{~kJ} / \mathrm{mol}$, which is close to the value for ionic resistances according to Ogihara et al. ${ }^{27}(\approx 16 \mathrm{~kJ} / \mathrm{mol})$ and differs largely from the expected activation energy of electronic processes $\left(\approx 0.8 \mathrm{~kJ} / \mathrm{mol}\right.$ from Ogihara et al. $\left.{ }^{27}\right)$. In principle, there are three options where this interface can be allocated: a) the current collector/coating interface, b) the surface of the active material, or c) the coating/separator interface. The three interfaces can be distinguished distinctly by their activation energies and capacitances. For case a), the resistance would be an electron conduction resistance and one would expect a small activation energy $(<1 \mathrm{~kJ} / \mathrm{mol})^{28}$ and an active surface area of $\approx 1 \mathrm{~cm}^{2}$ corresponding to the current collector surface area. Thus, a typical double layer capacitance of non-aqueous electrolytes of $\approx 5 \mu \mathrm{F} / \mathrm{cm}^{2}$, a capacitance of $\approx 5 \mu \mathrm{F} / \mathrm{cm}^{2}$ geo. would be expected, which should be consistent with the value obtained from the analysis of the semicircle peak frequency. However, the capacitance of this newly formed interface is $73 \mu \mathrm{F} / \mathrm{cm}^{2}$ geo, so that case a) cannot be true. For case b), the activation energy should correspond to a charge transfer reaction (on the order to $\approx 50-60 \mathrm{~kJ} / \mathrm{mol})^{28}$ and the capacitance of the observed semicircle should be on the order of $10 \mathrm{mF} / \mathrm{cm}^{2}{ }_{\text {geo. }}$. based on a typical double layer capacitance of $5 \mu \mathrm{F} / \mathrm{cm}^{2}$ geo. and a roughness factor of $\approx 200 \mathrm{~cm}^{2}{ }_{\text {BET }} / \mathrm{cm}^{2}$ geo (based on a loading of $\approx 6.6 \mathrm{mg}_{\text {graphite }} / \mathrm{cm}^{2}$ and a graphite BET surface area of $3 \mathrm{~m}^{2} / \mathrm{g}$, as shown in the previous section). Thus, case b) is neither consistent with the obtained capacitance nor with the observed activation energy $(9 \mathrm{~kJ} / \mathrm{mol})$. In case c) the activation energy should correspond to a value typical for ionic conduction in the electrolyte $(\approx 10-20 \mathrm{~kJ} / \mathrm{mol})^{28}$ which is consistent with the data; in this case, the observed capacitance would suggest a thickness of this coating/separator interface layer of $\approx 10 \%$ of the anode electrode thickness. The formation of such a layer has also been hypothesized previously in order to explain the observed roll-over fading. ${ }^{26}$

Burns et al. ${ }^{26}$ explained the rapid capacity drop after extended cycling ( $>700$ cycles) of 18650 -sized graphite/NMC111 cells with a crosstalk phenomenon: electrolyte oxidation products from the cathode, which diffuse to the anode and are reduced on top of the graphite anode in the vicinity of the separator (i.e., at the anode/separator interface region). They suggested that after significant reaction of crosstalk species at this region, a sufficiently thick and dense layer would form in the anode electrode in this region, slowing down ion transport in the electrolyte phase and thus lowering the maximum C-rate at which the cell can be cycled. These conclusions were drawn from SEM top-view images of the anode/separator interface before and after cycling. For LNMO cathodes it is well known that transition metal dissolution ${ }^{7}$ (e.g., manganese dissolution) and subsequent deposition on the anode is a key failure mechanism of these cells, especially when cycled at elevated temperatures. Hence, a deposition of manganese at the anode/separator interface region accompanied by excessive SEI growth ${ }^{29-31}$ could lead to a region of low porosity in the graphite electrode layer adjacent to the separator and thus to a locally increased ionic resistance in the electrolyte phase. If so, this would be the most likely origin of the semi-circle in the anode blocking impedance spectra.

In order to prove this hypothesis, graphite/LFP cells (where no transition metal dissolution occurs under typical cycling conditions) were prepared without and with a defined amount $(50$ or $100 \mathrm{mM})$ of deliberately added Mn(TFSI $)_{2}$ salt to mimic the transition metal dissolution in LNMO/graphite cells. Formation of the graphite/LFP cells was done by two cycles at $\mathrm{C} / 10$ and $25^{\circ} \mathrm{C}$ from $2.0 \mathrm{~V}_{\mathrm{FC}}$ to 4.0 $\mathrm{V}_{\mathrm{FC}}$. After formation, five cycles at $\mathrm{C} / 2$ and $40^{\circ} \mathrm{C}$ from $1.5 \mathrm{~V}_{\mathrm{FC}}$ and $4.0 \mathrm{~V}_{\mathrm{FC}}$ were recorded and the impedance was measured at $1.5 \mathrm{~V}_{\mathrm{FC}}$ $\left(\mathrm{E}_{\mathrm{Gra}} \approx 1.87 \mathrm{~V}_{\mathrm{Li}}\right)$ under constant voltage conditions, after the current dropped below $\mathrm{C} / 100$. Three types of cells were investigated: (i) graphite/LFP cells cycled in pure LP57 electrolyte; (ii) graphite/LFP cells which first underwent formation in metal-free LP57 electrolyte, then were opened in an Ar-filled glove box, and finally reassembled with fresh separators and LP57 to which $50 \mathrm{mM} \mathrm{Mn(TFSI})_{2}$ has been added; and, (iii) graphite/LFP cells prepared as in (ii) but with LP57 with $100 \mathrm{mM} \mathrm{Mn}(\mathrm{TFSI})_{2}$ as the final electrolyte. Figure 6 shows the spectra in blocking configuration $\left(\mathrm{E}_{\mathrm{Gra}} \approx 1.87 \mathrm{~V}_{\mathrm{Li}}\right)$ after the $5^{\text {th }}$ cycle. The anode impedance spectrum of the cell with pure LP57 (in light blue) shows almost perfect blocking behavior - i.e., a transmission line followed by a capacitive branch (identical to the data in Figure 3). When $50 \mathrm{mM} \mathrm{Mn}(\mathrm{TFSI})_{2}$ were added to a graphite/LFP cell (in purple) the $45^{\circ}$ transmission line turns into a distinct semi-circle, expanding to a large semi-circle when the $\mathrm{Mn}(\mathrm{TFSI})_{2}$ concentration is increased to $100 \mathrm{mM}$ (in pink). From these results we conclude that manganese deposition and a concomitant enhanced SEI formation are also the cause for the semi-circle in the blocking anode impedance spectra of the graphite/LNMO cells (see Figure $4 \mathrm{~b}$ ). This in turn implies that transition metals are deposited preferentially in a thin layer within the graphite anode adjacent to the separator, in which an enhanced SEI formation occurs, blocking the electrolyte pores in this region of the graphite electrode (evident from the activation energy typical for ionic conduction). Studies on the analysis of the SEI distribution across the thickness of graphite anodes are currently under way to validate this hypothesis.

Anode impedance spectra fitting of graphite/LNMO cells under blocking and non-blocking conditions.-In the following, graphite 


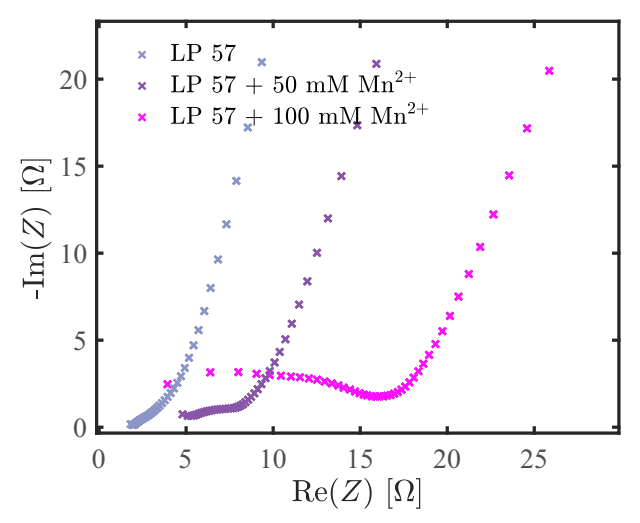

Figure 6. Impedance spectra of a graphite anode measured versus the GWRE in graphite/LFP cells with and without added Mn(TFSI $)_{2}$ to the electrolyte after formation in metal-free LP57 ( 2 cycles at C/10 with a CCCV charge and a CC discharge at $25^{\circ} \mathrm{C}$ ). Light blue: 5 cycles at $\mathrm{C} / 2$ at $40^{\circ} \mathrm{C}$ between $1.5-4.0$ $\mathrm{V}_{\mathrm{FC}}$; purple line: after formation, the cell was reassembled with new separators and refilled with LP57 $+50 \mathrm{mM} \mathrm{Mn(TFSI})_{2}$ and then cycled 5 times C/2 at $40^{\circ} \mathrm{C}$ between 1.5-4.0 $\mathrm{V}_{\mathrm{FC}}$; pink line: same as for the purple line, except that $100 \mathrm{mM} \mathrm{Mn}(\mathrm{TFSI})_{2}$ were used. The impedance is recorded at $1.5 \mathrm{~V}_{\mathrm{FC}}$ $\left(\mathrm{E}_{\mathrm{Gra}} \approx 1.87 \mathrm{~V}_{\mathrm{Li}}\right)$ under blocking conditions after the current dropped below $\mathrm{C} / 100$ at $40^{\circ} \mathrm{C}$.

anode impedance spectra of a graphite/LNMO cell cycled at $\mathrm{C} / 2$ and $40^{\circ} \mathrm{C}$ (see Figure 4) are fitted simultaneously for a given cycle in both blocking and non-blocking conditions, using the equivalent circuit shown in Figure 7 . The used equivalent circuit consists of: (i) a separator resistance $\left(R_{\text {Sep. }}\right)$ representing the ionic resistance within the separator (section I of the equivalent circuit given in Figure 7); (ii) an R/Q element for the futheron called "ionic contact resistance" $\left(R_{\text {Cont.Ion }}\right)$, which represents the increased ionic transport resistance of a thin layer in the graphite electrode adjacent to the separator and accounts for the semi-circle evolving in the anode blocking impedance spectra (section II in Figure 7); (iii) the general transmission line model composed of differential elements for the charge transfer resistance $\left(r_{\mathrm{CT}}\right)$ connected in parallel with the double layer capacitance $\left(q_{\mathrm{CT}}\right)$, the pure ionic $\left(r_{\text {Pore }}\right)$ and electrical resistance $\left(r_{\mathrm{El}}\right.$; here assumed to be negligible compared to $r_{\text {Pore }}{ }^{32}$ due to the high electronic conductivity of graphite) in the porous anode $\left(R_{\text {Pore }}\right)$, which is section III in Figure 7; and, (iv) a Warburg diffusion element (W, section IV in Figure 7), accounting for concentration gradients within the separator (discussed in Part $\mathrm{I}^{19}$ of this study). The interested reader is referred to Ref. 19 for details on the simultaneous fitting procedure. As the $45^{\circ}$ transmission line is only observable in the very first cycles (afterwards, the ionic contact resistance $\left(R_{\text {Cont.Ion }}\right)$ dominates in the impedance spectra), the pore resistance is fitted from the spectrum of the first cycle (Figure 4b) using a transmission line model (see Figure 7) without the R/Q element for the ionic contact resistance, and fixed for all the

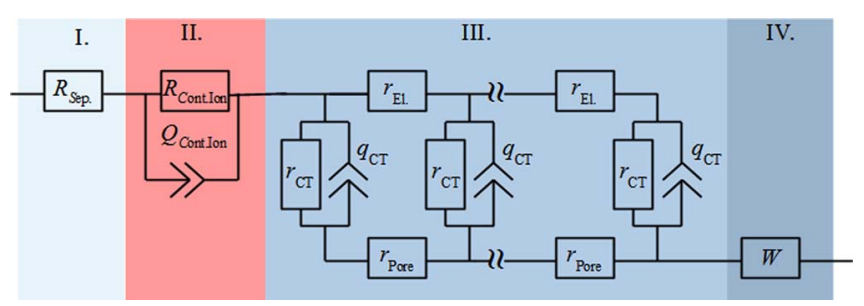

Figure 7. Anode equivalent circuit model with four sections (from left to right): I. separator resistance $\left(R_{\text {Sep }}\right)$ from the ionic resistance of the separator and the electronic/contact resistances of the cell setup; II. the "ionic contact resistance", representing the increased ionic transport resistance of a thin layer in the graphite electrode adjacent to the separator; III. the general transmission line model (TLM) describing the porous anode electrode; and, IV. a Warburg diffusion element describing concentration gradients within the separator.
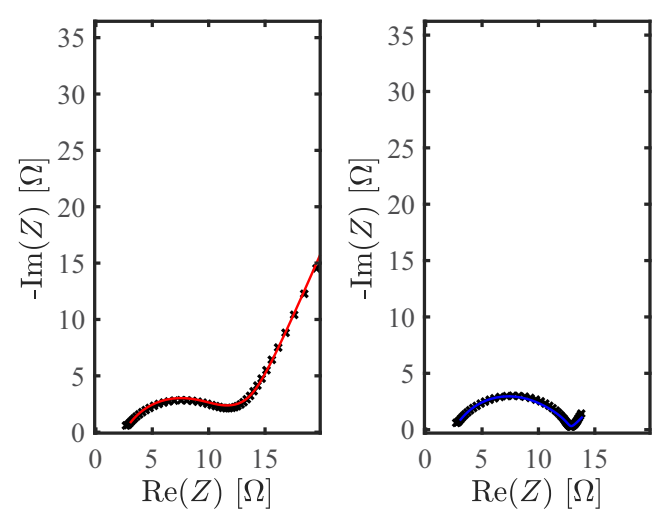

Figure 8. Exemplary fits (shown as solid lines) of the graphite anode impedance in a graphite/LNMO cell after the $30^{\text {th }}$ cycle (at $\mathrm{C} / 2$ at $40^{\circ} \mathrm{C}$ between 3.0-4.9 $\mathrm{V}_{\mathrm{FC}}$ ) in blocking condition (left) at $3.0 \mathrm{~V}_{\mathrm{FC}}$ and non-blocking conditions at $4.4 \mathrm{~V}_{\mathrm{FC}}$ corresponding to $\approx 10 \%$ SOC (right). Both spectra are fitted simultaneously using the equivalent circuit shown in Figure 7. AC impedance spectra (black crosses) were recorded at $40^{\circ} \mathrm{C}$ between $100 \mathrm{kHz}$ and $100 \mathrm{mHz}$ with a perturbation of $15 \mathrm{mV}$.

subsequent cycles to its $1^{\text {st }}$ cycle value. The obtained $1^{\text {st }}$ cycle pore resistance is $\approx 10.6 \Omega \mathrm{cm}^{2}$, with an uncertainy of $\pm 17 \%$ (confidence interval based on a $95 \%$ standard deviation).

Figure 8 shows one of the exemplary simultaneous fit results of the graphite anode impedance for the $30^{\text {th }}$ cycle. The black crosses in Figure 8a show the EIS data under blocking conditions $\left(3.0 \mathrm{~V}_{\mathrm{FC}}\right.$ recorded under $\mathrm{CV}$ conditions and after the current dropped below $\mathrm{C} / 100$, black crosses) and the fit is given by the red line. Figure $8 \mathrm{~b}$ shows the spectrum under non-blocking conditions (at $4.4 \mathrm{~V}_{\mathrm{FC}}$ corresponding to $\approx 10 \%$ SOC; recorded at $\mathrm{OCV}$ ) with experimental data (black crosses) and the corresponding fit (blue line). The following parameters are fitted from the blocking and non-blocking spectrum: $R_{\text {Sep. }}, R_{\text {Cont.Ion }}, Q_{\text {Cont.Ion }}, \alpha_{\text {Cont.Ion }}, R_{\text {CT-non-blocking }}, R_{\text {CT-blocking }}, Q_{\mathrm{CT}}, \alpha_{\mathrm{CT}}$ and the Warburg element $W$. The pore resistance $\left(R_{\text {Pore }}\right)$ and the electronic resistance ( $R_{\mathrm{El}}$, assumed as $1 \mathrm{~m} \Omega$ for the graphite anode) are fixed for all cycles. Table I summarizes the fitting results obtained from simultaneous fitting of the two spectra from cycle 30 .

Figure 9 presents the fitting results from simultaneously fitting the blocking and non-blocking spectra for each cycle over 86 cycles. Figure 9a shows the absolute values of the fitted resistances normalized to the geometrical area of the graphite electrode, whereas Figure $9 \mathrm{~b}$ shows the fitted resistances normalized to their value in the first cycle $\left(R / R_{1}\right)$. The fitted ionic contact resistance $\left(R_{\text {Cont.Ion }}\right)$, which we ascribe to the increased ionic transport resistance of a thin

Table I. Fit parameters of the equivalent circuit in Figure 7 for a simultaneous fit of impedance spectra under blocking conditions $\left(\boldsymbol{R}_{\text {CT-blocking }}\right)$ and non-blocking conditions $\left(\boldsymbol{R}_{\mathrm{CT} \text {-non-blocking }}\right)$ taken in cycle 30 (see Figure 8). The geometrical area of the electrode is $0.95 \mathrm{~cm}^{2}$. The error describes the confidence interval based on a $95 \%$ standard deviation (obtained using the confint function in Matlab).

\begin{tabular}{ll}
\multicolumn{1}{c}{ Parameter } & Value \\
\hline$R_{\text {Sep. }}$ & $2.4 \Omega \pm 16 \%$ \\
$R_{\text {Cont. Ion }}$ & $7.3 \Omega \pm 6.1 \%$ \\
$Q_{\text {Cont. Ion }}$ & $90 \mu \mathrm{F} \cdot \mathrm{s}^{\left(\alpha_{\text {Cont. }}-1\right)} \pm 21 \%$ \\
$a_{\text {Cont. Ion }}$ & $0.74 \pm 4.3 \%$ \\
$R_{\text {Pore }}$ & $10.6 \Omega \pm 17 \%$ (fixed to $1^{s t}$ cycle value) \\
$R_{\text {El. }}$ & $1 \mathrm{~m} \Omega$ (fixed) \\
$R_{\mathrm{CT}-\text { non-blocking }}$ & $0.8 \Omega \pm 19 \%$ \\
$R_{\mathrm{CT}-\text { blocking }}$ & $9 \cdot 10^{8} \Omega$ \\
$Q_{\mathrm{CT}}$ & $6.7 \mathrm{mF} \cdot \mathrm{s}^{\left(\alpha_{\mathrm{CT}}-1\right)} \pm 3.4 \%$ \\
$a_{\mathrm{CT}}$ & $0.74 \pm 0.50 \%$ \\
$W$ & $0.9 \Omega / \sqrt{s} \pm 31 \%$
\end{tabular}



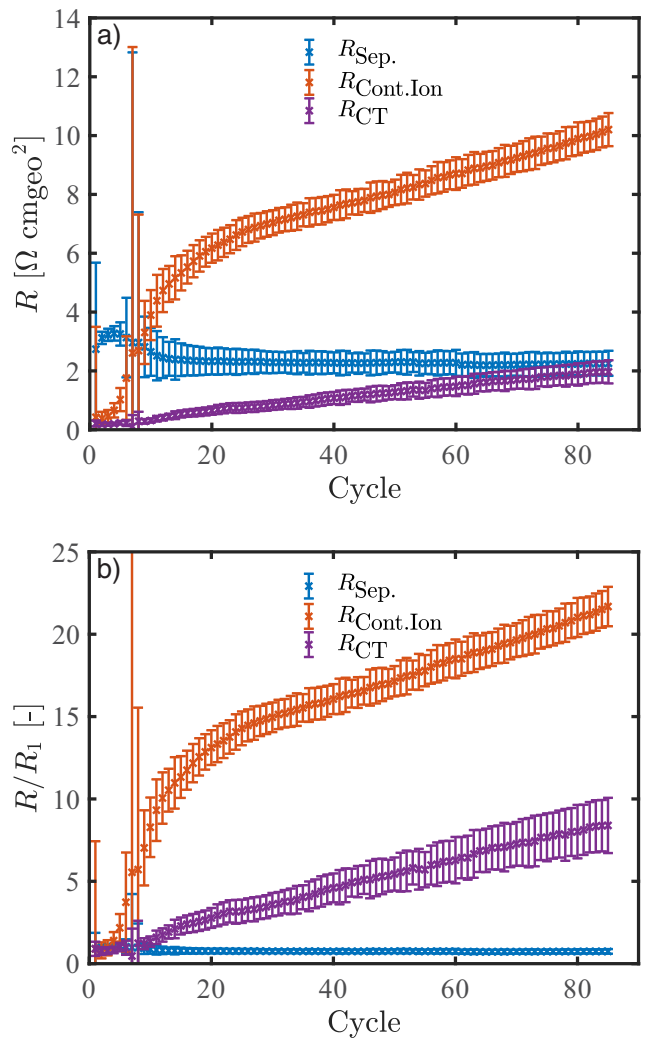

Figure 9. a) Evolution of the high frequency resistance $\left(R_{\text {Sep. }}\right)$, the charge transfer resistance $\left(R_{\mathrm{CT}}\right)$ and the ionic contact resistance $\left(R_{\text {Cont.Ion }}\right)$ of the graphite anode (normalized to the electrode area) in the LNMO/graphite fullcell over extended charge/discharge cycling between 3.0 and $4.9 \mathrm{~V}_{\mathrm{FC}}$ at $40^{\circ} \mathrm{C}$ and $\mathrm{C} / 2$. The values are obtained by simultaneously fitting impedance spectra in blocking ( $4.4 \mathrm{~V}_{\mathrm{FC}}$, corresponding to $\approx 10 \%$ SOC) and non-blocking (3.0 $\mathrm{V}_{\mathrm{FC}}$ ) conditions for each cycle. $\mathrm{b}$ ) Resistances normalized to their initial value after formation. The error bars represent the $95 \%$ confidence intervals of the fitted resistances.

layer in the graphite electrode adjacent to the separator is small in the beginning and then increases rapidly to $\approx 5 \Omega \mathrm{cm}^{2}$ until cycle 18 . Afterwards, it increases only gradually, reaching $R_{\text {Cont.Ion }} \approx 10 \Omega \mathrm{cm}^{2}$ after 86 charge/discharge cycles at $40^{\circ} \mathrm{C}$. The separator resistance $\left(R_{\text {Sep. }}\right)$ has a value of $\approx 2.4 \Omega \mathrm{cm}^{2}$ after formation and stays constant during cycling. The charge transfer resistsance $\left(R_{\mathrm{CT}}\right)$ increases from $\approx 0.2 \Omega \mathrm{cm}^{2}$ after formation to $\approx 2 \Omega \mathrm{cm}^{2}$ after 86 cycles, which is likely due to a continuous growth of the graphite SEI. The normalized values in Figure $9 \mathrm{~b}$ show that while $R_{\text {Sep. }}$ stays constant during cycling, $R_{\text {Cont.Ion }}$ increases by a factor of 20 and the SEI/charge transfer resistance $\left(R_{\mathrm{CT}}\right)$ increases linearely by a factor of 5 . As already stated above, the ionic contact resistance $\left(R_{\text {Cont.Ion }}\right)$ increases very rapidly in the beginning and then flattens out, which could be explained by the following scenario: In the beginning, the deposited manganese ions lead to a strong SEI formation. After several charge/discharge cycles, the insulating SEI layer on the graphite particle surface may be sufficiently thick to slow down preferential manganese deposition near the separator interface, leading to a more homogeneous SEI growth across the anode. Due to the dominating $R_{\text {Cont.Ion }}$ a deconvolution of the SEI resistance (covered over the whole graphite electrode) from the charge transfer resistance is not possible. However we are currently trying this deconvolution in graphite/LFP cells with the same blocking/non-blocking approach. ${ }^{25}$

Overview-LNMO/graphite full-cell impedance.-Based on our previous analysis of the LNMO cathode of LNMO/graphite cells ${ }^{19}$ and the above investigation of the graphite anode impedance contributions,

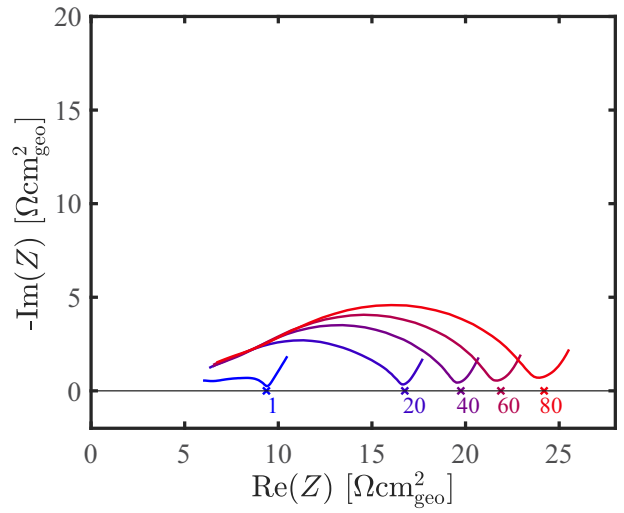

Figure 10. Full-cell impedance spectra of LNMO/graphite cells at $40^{\circ} \mathrm{C}$ from cycle 1 (blue) to cycle 80 (red; cycle numbers are given in the figure), measured at $4.4 \mathrm{~V}_{\mathrm{FC}}(\approx 10 \% \mathrm{SOC})$, in the frequency range from $100 \mathrm{kHz}$ to $0.1 \mathrm{~Hz}$ using an excitation amplitude of $15 \mathrm{mV}$. Crosses on the $\mathrm{x}$-axis indicate the low frequency extrapolation (LFE, last 3 frequency points) which are shown as $R_{\text {Full-Cell }}(\mathrm{LFE})$ in Figure 12.

we are now able to combine all impedance results and compare them to the full-cell spectra.

Figure 10 shows the increase of the LNMO/graphite full cell impedance in non-blocking conditions, i.e., at a full cell potential of $4.4 \mathrm{~V}_{\mathrm{FC}}(\approx 10 \% \mathrm{SOC})$, over the course of cycling. The idea of showing Figure 10 is to exemplify the ambiguity in the impedance analysis of full-cell spectra, which include anode and cathode impedance contributions. The full-cell impedance mainly shows a single smeared out semi-circle in the Nyquist plot, with a low frequency resistance (inflection point) of $\approx 10 \Omega \mathrm{cm}^{2}$ in cycle 1 up to $\approx 25 \Omega \mathrm{cm}^{2}$ in cycle 80 . From the analysis of full-cells measured to higher frequencies (see text in Part I of this study ${ }^{19}$ ), we could show that the full-cell high frequency resistance equals $\approx 4.8 \Omega \mathrm{cm}^{2}$. Based on this known value of the high frequency resistance we were able to show that the full-cell EIS response includes a second R/Q feature at very high frequencies, which could be ascribed to a contact resistance at the interface between the cathode electrode and the aluminum current collector $\left(R_{\text {Cont.Cath. }}\right){ }^{19}$

Thus, while only two features could be discerned in the full-cell graphite/LNMO impedance spectra, the combined use of a microreference electrode (GWRE) and of simultaneously fitting blocking and non-blocking impedance spectra in every cycle, we could successfully disentangle not only the origin of the observed $\approx 4$ fold increase of the full-cell low frequency resistance (note that the separator resistance is invariant at $\approx 4.8 \Omega \mathrm{cm}^{2}$ ) but also quantify the individual resistances.

In order to visualize the disentangled resistance contribution a schematic overview of a graphite/LNMO cell is depicted in Figure 11. The individual resistances are: the ionic resistance in the electrolyte

\section{Cathode (LNMO) Sep. Anode (Graphite)}

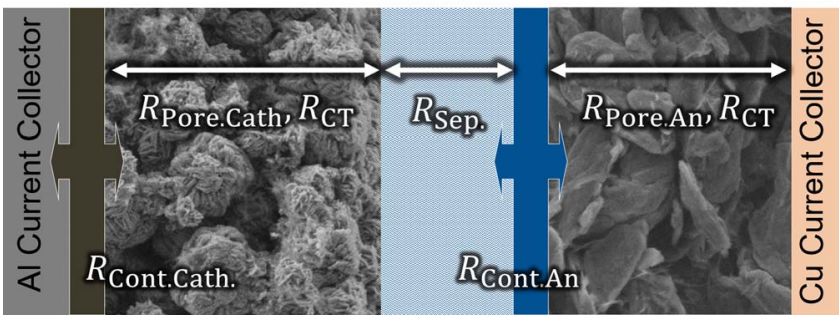

Figure 11. Schematic drawing of a graphite/LNMO cell with (from left to right) the cathode current collector, the porous LNMO electrode, the separator, the porous graphite electrode and the anode current collector. The disentangled resistances are marked in the schematic drawing. 


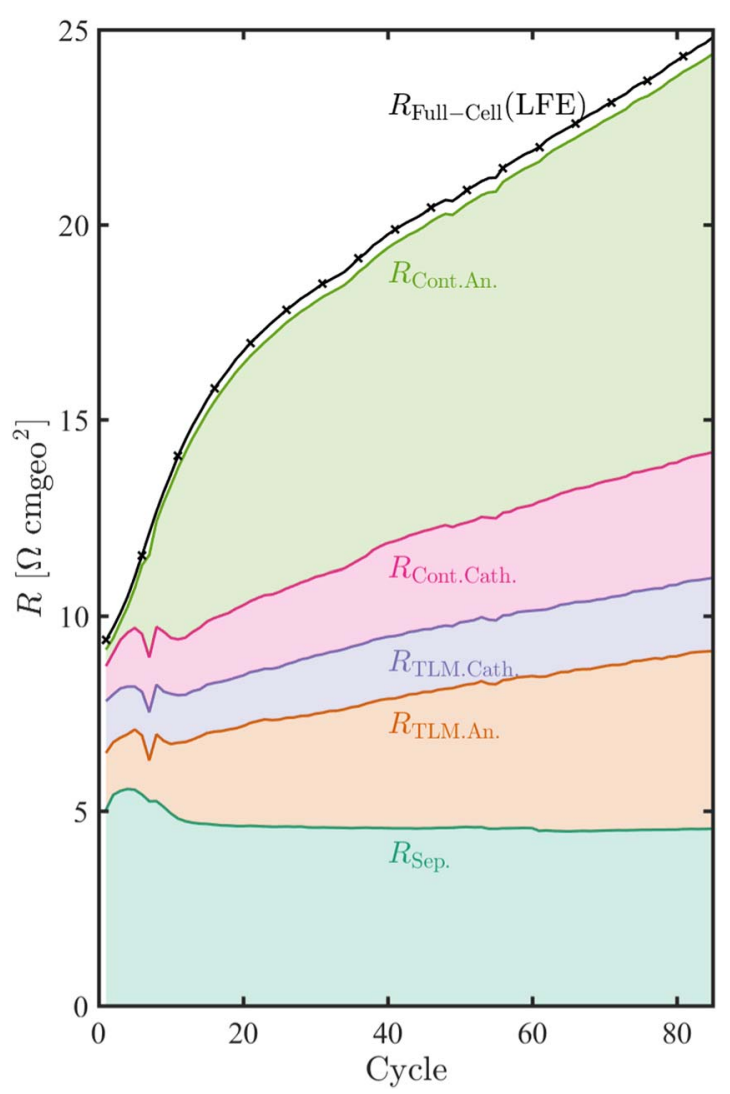

Figure 12. Evolution of the various impedance contributions in a graphite/LNMO full-cell upon extended cycling at $\mathrm{C} / 2$ and $40^{\circ} \mathrm{C}$. Individual contributions were determined using half-cell impedance spectra obtained by means of a micro-reference electrode (GWRE) in combination with simultaneously fitting two impedance spectra for each cycle, namely one under blocking and one under non-blocking conditions (from bottom to top): (i) the total HFR resistance due to the separator resistance $\left(R_{\text {Sep. }}\right)$; (ii) the anode resistance described by the transmission line model (TLM), a convolution of $R_{\text {Pore }}$ and $R_{\mathrm{CT}}$ of the anode $\left(R_{\text {TLM.An. }}\right)$; (iii) the cathode TLM resistance, a convolution of $R_{\text {Pore }}$ and $R_{\text {CT }}$ of the cathode $\left(R_{\text {TLM.Cath. }}\right)$; (iv) the contact resistance at the cathode / current collector interface $\left(R_{\text {Cont.Cath. }}\right)$; and, $(\mathrm{v})$ the pore resistance in a thin layer of the anode electrode adjacent to the separator $\left(R_{\text {Cont.Ion }}\right.$ (at the anode)). The extrapolated low frequency resistance of the full-cell impedance is also plotted as a reference ( $R_{\text {Full-Cell }}(\mathrm{LFE})$ ) and illustrates the good agreement between the half-cell analyses and the full-cell impedance (every fifth cycle indicated by cross, see Figure 10).

phase within anode and cathode pores $\left(R_{\text {Pore.An. }}\right.$ and $\left.R_{\text {Pore.Cath. }}\right)$, the anode and cathode charge transfer resistance $\left(R_{\mathrm{CT}-\text { non-blocking }}\right.$, evaluated at $\approx 10 \%$ SOC), the contact resistance at the current collector/cathode interface $\left(R_{\text {Cont.Cath. }}\right)$ and the ionic contact resistance $\left(R_{\text {Cont.Ion. }}\right)$ in the anode/separator region. The evolution of these resistances over extended charge/discharge cycling of a graphite/LNMO full-cell is summarized in Figure 12.

Figure 12 shows the total separator resistance $\left(R_{\text {Sep. }}\right)$, mainly remaining constant over the course of 86 cycles, the cathode contact resistance at the cathode/current collector interface ${ }^{19}\left(R_{\text {Cont.Cath. }}\right)$, the pore resistance in a thin layer of the anode electrode adjacent to the separator ( $R_{\text {Cont.Ion }}$ (at the anode), described in the previous sections), as well as the resistances obtained from the simplified transmission line model for both anode and cathode $\left(R_{\text {TLM.An. }}\right.$ and $\left.R_{\text {TLM.Cath. }}\right)$ which include the respective charge transfer and the pore resistances. It is emphasized that the resistance contributions from the ionic resistance with the anode/cathode pores $\left(R_{\text {Pore }}\right)$ and the respective anode/cathode charge transfer resistance (including the anode SEI resistance) cannot be added individually in this figure (as was done in Figure 9), since these two resistance elements are not serially connected in the transmission line model and, consequently, not additive with regards to the total effective resistance. Therefore, rather than showing $R_{\text {Pore }}$ and $R_{\mathrm{CT}}$ individually, Figure 12 shows the low frequency resistance of the simplified transmission line model $\left(R_{\mathrm{TLM}}(f \rightarrow 0)\right.$, neglecting electronic resistances) instead of individual values for $R_{\text {Pore }}$ and $R_{\mathrm{CT}}$. In the low frequency limit, the simplified transmission line model yields a low frequency resistance of

$$
R_{\mathrm{TLM}}(f \rightarrow 0)=\frac{\sqrt{R_{\text {Pore }} \cdot R_{\mathrm{CT}}}}{\tanh \left(\sqrt{\frac{R_{\text {Pore }}}{R_{\mathrm{CT}}}}\right)}
$$

which is independent of the surface capacitance $\left(Q_{\mathrm{CT}}\right)$. The reader is referred to the previous section as well as part I of this work ${ }^{19}$ regarding the absolute values for pore resistance and charge transfer of the LNMO cathode. Figure 12 shows the full-cell low frequency extrapolation (LFE), here we used the intercept of the linear extrapolation of the last three frequency points (compare Figure 10) with the $\mathrm{x}$-axis. The cumulative sum of all the individual resistance contributions shown in Figure 12 is in very good agreement with $R_{\text {Full-Cell }}$ (LFE) obtained from the full-cell spectra.

In summary, the impedance spectra of full-cells over the course of extended charge/discharge cycling can be analyzed for their individual resistance contributions by means of a micro-reference electrode and the simultaneous fitting of spectra under both non-blocking and blocking conditions (the requirements for the latter are different for different active materials). This approach was shown exemplarily for LNMO/graphite cells in Part I of this work ${ }^{19}$ as well as in the current study. It allows to get a profound understanding of the individual aging mechanisms in full-cells based on in-situ impedance measurements, going quite beyond of what would be possible by the symmetric cell diagnostics, where blocking conditions for a given electrode could not be attained. The mechanistic insights which can be obtained by our new approach are illustrated in Figure 9 and Figure 12, revealing the strong impedance buildup at the graphite anode/separator interface which could not have been discerned in the full-cell impedance data (Figure 10) nor in the anode impedance data under the conventionally used non-blocking conditions (Figure 4a). Similarly, the major impedance contribution during the aging of the LNMO cathode in a graphite/LNMO full-cell, viz., the growing contact resistance at the cathode/current collector interface, ${ }^{19}$ could not have been detected by the conventional impedance analysis approach. Therefore, we are certain that the application of the presented impedance analysis methodology will help to get a better understanding of the dominant aging mechanisms when cycling full-cells based on a variety of cell chemistries.

\section{Conclusions}

Using a gold wire micro-reference electrode (GWRE), the evolution of the graphite anode impedance of a graphite/LNMO is analyzed over the course of 86 charge/discharge cycles at $40^{\circ} \mathrm{C}$. First, we show that a graphite anode in a graphite/LFP full cell can be brought into blocking conditions, yielding the expected transmission line mode response which enables a more detailed analysis of the overall graphite impedance. However, when the cathode in the graphite/LFP full-cell is replaced by LNMO, the graphite impedance spectrum under blocking conditions shows an unexpected additional semi-circle at rather high frequencies. This feature evolves over 86 cycles in a graphite/LNMO cell and becomes the dominating contribution to the overall anode as well as to the overall full-cell impedance. By analyzing both temperature-dependent impedance measurements and the effect of the addition of manganese ions to the electrolyte in graphite/LFP cells, we are able to show that the observed semi-circle in the anode impedance spectra can be ascribed to an increased ionic transport resistance within a thin layer in the graphite electrode adjacent to the separator. By fitting simultaneously the impedance spectra for each given charge/discharge cycle under both blocking and nonblocking spectra with a general transmission line model (TLM), the anode impedance can ultimately be deconvoluted into its contributions 
from the ionic transport resistance in the separator $\left(R_{\mathrm{Sep}}\right)$, from the interfacial charge transfer/SEI resistance, and from this newly measured ionic resistance at the anode/separator interface.

\section{Acknowledgment}

Financial support by the BASF SE through its Research Network on Electrochemistry and Batteries is gratefully acknowledged. J. L. gratefully acknowledges the funding by the BMBF (Federal ministry of Education and research, Germany) for its financial support under the auspices of the ExZellTUM II project, grant number 03XP0081.

\section{ORCID}

Daniel Pritzl (D) https://orcid.org/0000-0002-9029-107X

Johannes Landesfeind (10 https://orcid.org/0000-0003-0333-2185

Sophie Solchenbach (1) https://orcid.org/0000-0001-6517-8094

\section{References}

1. Frank Holmes, https://www.forbes.com/sites/greatspeculations/2018/02/27/the worlds-cobalt-supply-is-in-jeopardy/ (2018).

2. D. Andre, S.-J. Kim, P. Lamp, S. F. Lux, F. Maglia, O. Paschos, and B. Stiaszny, J. Mater. Chem. A, 3, 6709 (2015).

3. D. Lu, M. Xu, L. Zhou, A. Garsuch, and B. L. Lucht, J. Electrochem. Soc., 160, A3138 (2013).

4. L. Yang, B. Ravdel, and B. L. Lucht, Electrochem. Solid-State Lett., 13, A95 (2010).

5. J.-H. Kim, N. P. W. Pieczonka, and L. Yang, ChemPhysChem, 15, 1940 (2014).

6. S. R. Li, C. H. Chen, X. Xia, and J. R. Dahn, J. Electrochem. Soc., 160, A1524 (2013)

7. N. P. W. Pieczonka, Z. Liu, P. Lu, K. L. Olson, J. Moote, B. R. Powell, and J.-H. Kim, J. Phys. Chem. C, 117, 15947 (2013).

8. P. Lu, C. Li, E. W. Schneider, and S. J. Harris, J. Phys. Chem. C, 118, 896 (2014).

9. S. S. Zhang, K. Xu, and T. R. Jow, Electrochim. Acta, 51, 1636 (2006).
10. S. Zhang, M. S. Ding, K. Xu, J. Allen, and T. R. Jow, Electrochem. Solid-State Lett., 4, A206 (2001)

11. S. S. Zhang, J. Power Sources, 163, 713 (2007)

12. S. Solchenbach, D. Pritzl, E. J. Y. Kong, J. Landesfeind, and H. A. Gasteiger, J. Electrochem. Soc., 163, A2265 (2016).

13. C. H. Chen, J. Liu, and K. Amine, J. Power Sources, 96, 321 (2001).

14. R. Petibon, C. P. Aiken, N. N. Sinha, J. C. Burns, H. Ye, C. M. VanElzen, G. Jain, S. Trussler, and J. R. Dahn, J. Electrochem. Soc., 160, A117 (2013).

15. M. Klett, J. A. Gilbert, S. E. Trask, B. J. Polzin, A. N. Jansen, D. W. Dees, and D. P. Abraham, J. Electrochem. Soc., 163, A875 (2016).

16. J. Zhou and P. H. L. Notten, J. Electrochem. Soc., 151, A2173 (2004)

17. M. Ender, A. Weber, and E. Ivers-Tiffée, J. Electrochem. Soc., 159, A128 (2012).

18. A. N. Jansen, D. W. Dees, D. P. Abraham, K. Amine, and G. L. Henriksen, J. Power Sources, 174, 373 (2007)

19. J. Landesfeind, D. Pritzl, and H. A. Gasteiger, J. Electrochem. Soc., 164, A1773 (2017).

20. D. Pritzl, S. Solchenbach, M. Wetjen, and H. A. Gasteiger, J. Electrochem. Soc., 164, A2625 (2017).

21. M. Metzger, B. Strehle, S. Solchenbach, and H. A. Gasteiger, J. Electrochem. Soc., 163, A798 (2016)

22. J. Landesfeind, J. Hattendorff, A. Ehrl, W. A. Wall, and H. A. Gasteiger, J. Electrochem. Soc., 163, A1373 (2016).

23. D. J. Xiong, R. Petibon, M. Nie, L. Ma, J. Xia, and J. R. Dahn, J. Electrochem. Soc., 163, 546 (2016).

24. M. Gaberscek, J. Moskon, B. Erjavec, R. Dominko, and J. Jamnik, Electrochem. Solid-State Lett., 11, A170 (2008)

25. D. Pritzl, A. Bumberger, M. Wetjen, J. Landesfeind, S. Solchenbach, and H. A. Gasteiger, Manuscr. prep..

26. J. C. Burns, A. Kassam, N. N. Sinha, L. E. Downie, L. Solnickova, B. M. Way, and J. R. Dahn, J. Electrochem. Soc., 160, A1451 (2013).

27. N. Ogihara, S. Kawauchi, C. Okuda, Y. Itou, Y. Takeuchi, and Y. Ukyo, J. Electrochem. Soc., 159, A1034 (2012).

28. N. Ogihara, S. Kawauchi, C. Okuda, Y. Itou, Y. Takeuchi, and Y. Ukyo, J. Electrochem. Soc., 159, A1034 (2012)

29. M. Ochida, Y. Domi, T. Doi, S. Tsubouchi, H. Nakagawa, T. Yamanaka, T. Abe, and Z. Ogumi, J. Electrochem. Soc., 159, A961 (2012).

30. C. Zhan, J. Lu, A. Jeremy Kropf, T. Wu, A. N. Jansen, Y. K. Sun, X. Qiu, and K. Amine, Nat. Commun., 4, 1 (2013).

31. T. Joshi, K. Eom, G. Yushin, and T. F. Fuller, J. Electrochem. Soc., 161, 1915 (2014)

32. J. Landesfeind, M. Ebner, A. Eldiven, V. Wood, and H. A. Gasteiger, J. Electrochem. Soc., 165, 469 (2018). 